\title{
FACTORS ANALYSIS OF FOOTWEAR TRADE INDUSTRY OF INDONESIA MAIN EXPORT DESTINATION
}

\section{Darwin Simanjuntak*}

\begin{abstract}
This study aims to identify the factor that affecting the footwear trade industry in Indonesia based on Indonesia main export destination. Understanding these factors could help leaders in trade industry institutions to better plan their strategies and further research on footwear trading. A set of data was obtained from Badan Pusat Statistic (BPS) based on data from Indonesia footwear main export destination namely: United States, China, Belgium, Germany, Japan, United Kingdom, Netherlands, Korea, Italy, Australia, Mexico, France, Canada, Denmark, Singapore, Brazil, Hong Kong, Russian Federation, Chile, Argentina and Other Countries. Exploratory factor analysis was used to identify the underlying dimensions of countries as Indonesia main export destination. By applying the factor analysis, the study will decide the number of factors to be retained and the total variance explained by these factors; the study can identify the variables in each factor retained in the final solution, on the basis of its factor loadings; the study can give names to each factor retained on the basis of the nature of the variables included in it; the study can suggest the test battery for assessing the footwear trade main export destination in Indonesia; and the study can test the adequacy of sample size used in factor analysis. The result of the study shows that KMO value is 0.784 which is $>0.5$; hence, the sample size is adequate for the analysis and the commonalities of all the variables are more than .4; hence, all the variables are useful in the model. Since the variables are identified in factor 0.7 or more, the result shows that all factors which are from the year 2012-2016 contributed to the exports of footwear in Indonesia.
\end{abstract}

Keywords: Footwear, Factor Analysis, Export, Indonesia

Article history:

Received September 22, 2018; Revised Oktober 20, 2018; Accepted November 10, 2018

\section{Introduction}

Today the industry grows and grows rapidly. One of the industrial sectors that experienced a fairly tight competition is the footwear industry. Because the footwear industry in Indonesia has wide-open market opportunities both within and outside the country. Indonesia is a potential market for footwear products. One of the products that belong to the footwear industry is shoes. Shoes are one of the most needed equipment by the community in many ways, both for everyday needs and formal needs such as to work up to anything else needed to look neat. But entering the era of globalization, there is a fairly tight shoe industry competition caused by the number of imported shoe products that enter the market, especially China that offers products with cheaper prices, coupled with the emergence of brand new shoes that offer a very attractive design. This causes the shoe manufacturers to be able to compete in the fight for market share. The shoe business has a potential market share because the free market for the ASEAN region, Asia Pacific and the world, has been put into effect. Shoes are one of the readiest domestic commodities to compete in the free market. The threat faced is big enough that the competition between producers in fighting for the same consumer market is increasingly tight. The greatest sales potential from 2009. From the glory of leather export in 1986-1996 has been transformed into a glorious export of finished leather finished products that ranks third under textile and wood as the main non-oil export commodities of shoes, jackets, bags, and gloves. In the decade of the 1990s, Indonesia's skin became the target of the world's shoe industry, because the quality is very distinctive. Indonesia has fulfilled about 3 percent of the world's footwear needs. It is based on the data of export value in 2013 which reached the US $\$ 3.8$ billion or around $\mathrm{Rp} 44$ trillion. The value grew 
from 2012 which only reached the US \$ 3.6 billion or around Rp 42 trillion. But in the following years, the footwear industry has stagnated as it is adapted from the Ministry of Commerce's website. Stagnation or decline in footwear sales is influenced by internal factors such as the problem of labor and raw materials are less to support footwear production, thus slowing the country's economy. Nevertheless, this study aims to identify the factor that affecting the footwear trade industry in Indonesia based on Indonesia main export destination. Understanding these factors could help leaders in trade industry institutions to better plan their strategies and further research on footwear trading. Furthermore, there needs to be a new pattern or model of how all aspects of marketing and effective government roles constrict to the improvement of Indonesia's footwear industry in order to be more competitive in domestic and foreign markets.

\footnotetext{
* Norazlan Alias, Associate Professor, School of Management, Faculty of Economics and Management, Universiti Kebangsaan, Malaysia; Mohd Hasimi Yaacob, Senior Lecturer, School of Management, Faculty of Economics and Management, Universiti Kebangsaan Malaysia; Nahariah Jaffar, Associate Professor, Faculty of Management, Multimedia University, Malaysia

Corresponding author: norazlan@ukm.edu.my mhasimi@ukm.edu.my; nahariah@mmu.edu.my
} 


\section{Objectives of the Study}

Fewer studies explore simultaneously the influence of board of directors' structure and ownership structure on firm performance subsequent to corporate restructuring in the form of asset restructuring. Firm performance subsequent to corporate restructuring is also being influenced by the firm's financing policy and operating policy as discussed in the literature. Therefore, this study examines the influence of governance structure as depicted by board of directors' structure and ownership structure subsequent to operating asset disposal as part of asset restructuring scheme on firm performance and the influence of board of directors structure and ownership structure on capital structure policy as depicted by debt level and operating policy as depicted by diversification level subsequent to asset disposal. This study also examines the firm's characteristics as mentioned above prior to asset disposal's years to allow for a comparison on the effect of those characteristics prior and subsequent to corporate restructuring. Therefore, this study will document the link between governance structure, corporate policies, and performance.

\section{Literature Review}

Business strategy cannot be separated from marketing strategy. In marketing known 4P of Marketing are Product, Price, Promotion, and Place which can be translated as a product, price, promotion and location where company reside and market its product.

Product. The word product comes from the English "Product" product more shows on a manufactured (Kotler and Armstrong, 1996, Station, 1996). According to Tjiptono (2008) product classification is in two main groups namely goods and services and viewed from the aspect of its durability, it can be nondurable goods and durable goods. On the other hand, the product can also be divided into consumer goods (consumer goods) and industrial goods (industrial goods). One of the most important values customers expect from producers is the highest quality of products and services. A quality product will determine the quality of life of the company. In this era of globalization, society or consumers increasingly critical in assessing a product. From some of the problems faced by the business world in reaching customers include product quality, where consumers are increasingly critical and the number of choices of products and services offered, but the innovative business world will never stop looking for opportunities. Some experts pointed out what and how the quality of products that customers expect (Kotler, 2003; Tjiptono, 1999; Kotler, 2003; Nugroho Setiadi, 2003; Tjiptono, 2008; Parasuraman et al., 2003; Rangkuti, 2015) as well as those contained in the Standard National Indonesia where the quality is the overall characteristics and characteristics of products or services whose ability can satisfy the needs, whether expressed explicitly or undercover. 
J T I M B

Therefore, companies need to develop their product and service strategies (Kotler, 2003; David, 2008; Hunger and Wheelen, 2012; Leviti, 2003; Kotler \& Armstrong, 2004).

The price of the product is basically the amount paid by the customer to enjoy it. Price is a very important component in the definition of the marketing mix. (Kotler, 2016). It is also a very important component of the marketing plan because it determines the profit and survival of your company. Adjusting product prices has a major impact on the overall marketing strategy and greatly affects the sales and demand for the product. This is basically a sensitive area though. If a new company knows the market and has not made a name for themselves, it is unlikely your target market will be willing to pay the high price. Although they may be willing to hand over large sums of money, it is difficult to make it do so during the business birth. Price always helps shape your product perception in consumer's eyes. Always remember that low prices usually mean inferior goods in the eyes of consumers because comparing your goodness with competitors. As a result, too high a price will make the cost greater than the benefits in the eyes of the consumer.

\section{Methodology}

This study aims to identify the factor that affecting the footwear trade industry in Indonesia based on Indonesia main export destination. Understanding these factors could help leaders in trade industry institutions to better plan their strategies and further research on footwear trading. A set of data was obtained from Badan Pusat Statistic (BPS) based on data from Indonesia footwear main export destination namely: United States, China, Belgium, Germany, Japan, United Kingdom, Netherlands, Korea, Italy, Australia, Mexico, France, Canada, Denmark, Singapore, Brazil, Hong Kong, Russian Federation, Chile, Argentina and Other Countries. Exploratory factor analysis was used to identify the underlying dimensions of countries as Indonesia main export destination. By applying the factor analysis, the study will decide the number of factors to be retained and the total variance explained by these factors; the study can identify the variables in each factor retained in the final solution, on the basis of its factor loadings; the study can give names to each factor retained on the basis of the nature of the variables included in it; the study can suggest the test battery for assessing the footwear trade main export destination in Indonesia; and the study can test the adequacy of sample size used in factor analysis. The following relevant outputs have been selected for the discussion: Descriptive statistics, correlation matrix, KMO and Bartlett's test, Communalities of all the variables, total variance explained, scree plot, and component matrix: unrotated factor solution, and rotated component matrix: varimax-rotated solution. 


\section{Results}

Table 1 shows from the mean result of footwear exports that there is an increase in the last 2 years even though there is a decline from 2014-2015 based on the observation of 21 export destination countries.

Table 1. Descriptive statistics

\begin{tabular}{|l|l|r|r|}
\hline & Mean & Std. Deviation & Analysis N \\
\hline 2012 & 167.8095 & 195.38491 & 21 \\
2013 & 183.8571 & 223.18989 & 21 \\
2014 & 253.8095 & 350.99838 & 21 \\
2015 & 214.6190 & 274.42986 & 21 \\
2016 & 220.9524 & 282.14774 & 21 \\
\hline
\end{tabular}

Table 2 shows the correlation matrix of all the variables. The result shows that the correlation matrix is significant at 0.01 .

Table 2. Correlation Matrix

\begin{tabular}{|l|l|r|r|r|r|r|}
\hline & & \multicolumn{1}{c|}{2012} & \multicolumn{1}{c|}{2013} & \multicolumn{1}{c|}{2014} & \multicolumn{1}{c|}{2015} & \multicolumn{1}{c|}{2016} \\
\hline Correlation & 2012 & 1.000 & .996 & .672 & .982 & .967 \\
& 2013 & .996 & 1.000 & .658 & .988 & .978 \\
& 2014 & .672 & .658 & 1.000 & .648 & .633 \\
& 2015 & .982 & .988 & .648 & 1.000 & .996 \\
& 2016 & .967 & .978 & .633 & .996 & 1.000 \\
Sig. (1-tailed) & 2012 & & .000 & .000 & .000 & .000 \\
& 2013 & .000 & & .001 & .000 & .000 \\
& 2014 & .000 & .001 & & .001 & .001 \\
& 2015 & .000 & .000 & .001 & & .000 \\
& 2016 & .000 & .000 & .001 & .000 & \\
\hline
\end{tabular}




\section{J T I M B \\ Jurnal Terapan Ilmu Manajemen Dan Bisnis}

Table 3 shows the results of KMO test, which tells whether sample size taken for the factor analysis was adequate or not.

\section{Table 3. KMO and Bartlett's Test}

\begin{tabular}{|c|c|c|}
\hline \multicolumn{2}{|c|}{ Kaiser-Meyer-Olkin Measure of Sampling Adequacy. } & \\
\hline \multirow{3}{*}{$\begin{array}{l}\text { Bartlett's Test of } \\
\text { Sphericity }\end{array}$} & Approx. Chi-Square & 257.007 \\
\hline & df & 10 \\
\hline & Sig. & .000 \\
\hline
\end{tabular}

Based on the table above, the KMO value is 0.784 which is $>0.5$; hence, the sample size is adequate for the analysis. Further, the Bartlett test of sphericity is used to test the null hypothesis that the correlation matrix is an identity matrix. Since significant value ( $\mathrm{p}$-value) of the correlation matrix is 0.000 which is $<0.01$ hence it is significant, and the correlation matrix is not an identity matrix. Thus it may be concluded that the factor model is appropriate.

Table 4. Commonalities

\begin{tabular}{|c|c|c|}
\hline & Initial & Extraction \\
\hline 2012 & 1.000 & .975 \\
\hline 2013 & 1.000 & .978 \\
\hline 2014 & 1.000 & .558 \\
\hline 2015 & 1.000 & .977 \\
\hline 2016 & 1.000 & .960 \\
\hline
\end{tabular}

A higher commonality of a variable indicates that the major portion of its variability is explained by all the identified factors in the analysis. If commonality of the variable is $<.4$, it is considered to be useless and should normally be removed from the model. From table 4, it can be seen that the commonalities of all the variables are more than .4; hence, all the variables are useful in the model.

Table 5. Total Variance Explained

\begin{tabular}{|l|r|r|r|r|r|r|}
\hline \multirow{2}{*}{ Component } & \multicolumn{3}{|c|}{ Initial Eigenvalues } & \multicolumn{3}{c|}{$\begin{array}{c}\text { Extraction Sums of Squared } \\
\text { Loadings }\end{array}$} \\
\hline & Total & \% of Variance & Cumulative \% & Total & $\begin{array}{c}\text { \% of } \\
\text { Variance }\end{array}$ & $\begin{array}{c}\text { Cumulat } \\
\text { ive \% }\end{array}$ \\
\hline 1 & 4.448 & 88.958 & 88.958 & 4.448 & 88.958 & 88.958 \\
2 & .507 & 10.149 & 99.107 & & & \\
3 & .040 & .802 & 99.909 & & & \\
4 & .003 & .060 & 99.969 & & & \\
5 & .002 & .031 & 100.000 & & & \\
\hline
\end{tabular}


It can be seen that after rotation, the first factor explain $88.958 \%$ of the total variance, respectively. The eigenvalues for each of the factor are shown in the table. Only those factors are retained whose eigenvalues are 1 or more than 1 . Here, you can see that the eigenvalue for the first three factors is $>1$; hence, only one factor has been retained in this study.

Figure 1. Scree Plot

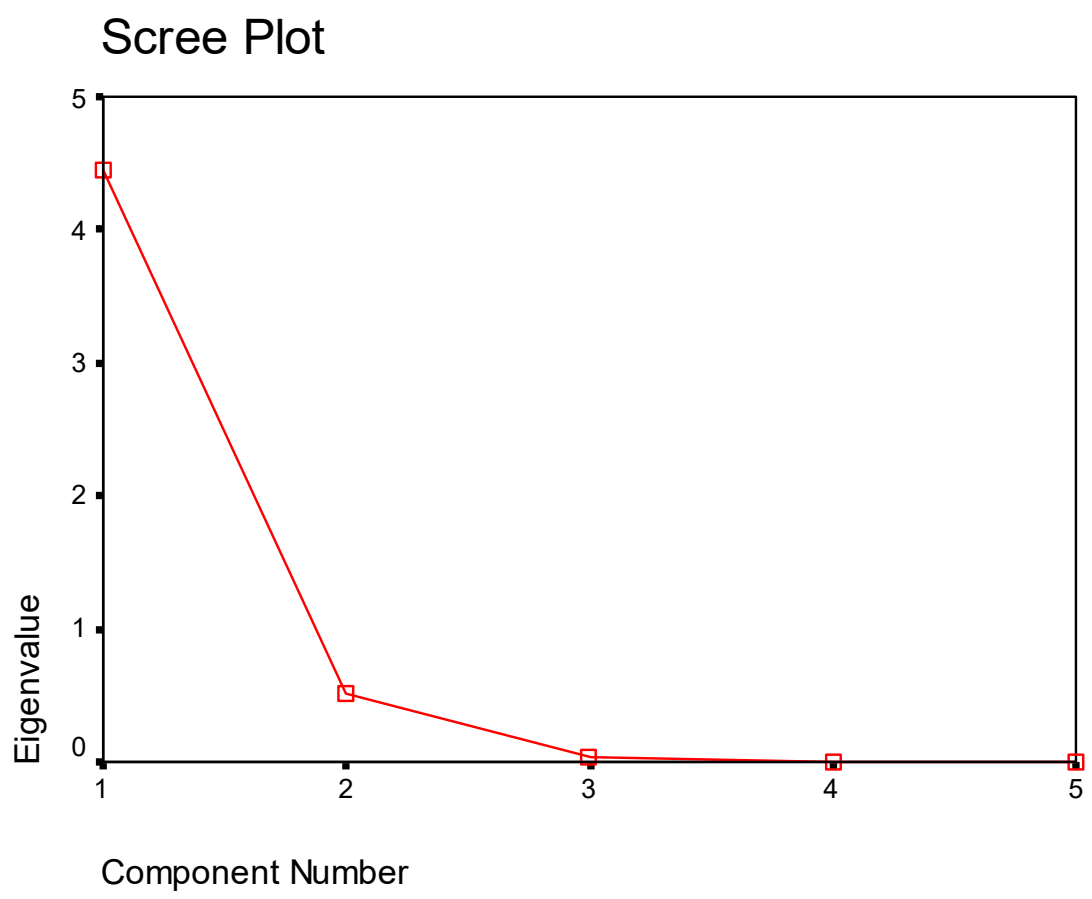

Figure 1 shows the scree plot which is obtained by plotting the factors (along Xaxis) against their eigenvalues along (Y-axis). This plot shows that only one factor has eigenvalues above elbow bent; hence, only three factors have been retained in this study.

Table 6. Component Matrix

\begin{tabular}{|c|c|c|}
\hline & Component & \\
\hline & 1 & \\
\hline 2012 & & .988 \\
\hline 2013 & & .989 \\
\hline 2014 & & .747 \\
\hline 2015 & & .988 \\
\hline 2016 & & .980 \\
\hline
\end{tabular}

The factor loadings of all the variables on each of the four factors have been shown in this table. Since this is an unrotated factor solution, and therefore some of the variables may show their contribution in more than one factor. 
In order to avoid this situation, the factors are rotated. The varimax rotation has been used in this example to rotate the factors, as this is the most popular method used by the researchers due to its efficiency.

Variables are usually identified in a factor if their loading on factor 0.7 or more. This ensures that the factor extracts sufficient variance from that variable. Based on the table above the result shows that all factors which are from the year 2012-2016 contributed to the exports of footwear in Indonesia.

\section{References}

Bempah, R. D. (2017). Perajin Sepatu Lokal Keluhkan Serbuan Produk Impor. Kompas, $4 \mathrm{~J}$ januari 2017. [Avaible at: www.kompas.com]

David, F. R. (2008). Strategi Management: Concepts and Cases. Pretince Hall.

Hunger, D. J. dan T. L. Wheelen. (2012). Strategic Management (13th ed.). Edition, Addison - Wesley Publishing Comp.

Kotler, P. dan G. Armstrong. (2004). Principles of Marketing (10th ed.). Pearson Education

Inc. UpperSaddle River, New Jersey.

Kotler, P. (2003). Marketing Management. New Jersey: Prentice Hall.

Kotler, P. (2016) Marketing Management, Pheonix, Prentice Hall.

Leviti, T. (2003). Marketing Classic, Yogyakarta: Amara Books.

Parasuraman, Zeithaml dan Berry. (2003). Delivering Service Quality, New York, Free Press.

Rangkuti, F. (2015). SWOT Balance Scorecard. Jakarta: PT. Gramedia Pustaka Umum.

Robbins, S. P. \& M. Coulter. (2014). Management (14th ed.). Pearson.

Siagian, S. P. (2006). Manajemen Strategik, Cetakan Kelima, Pt. Bumi Aksara.

Tjiptono, F. (1999). Strategi Pemasaran. Yogyakarta : ANDI Yogyakarta.

Tjiptono, F. (2003). Prinsip-prinsip Total Quality Service ( TQS). Yogyakarta: ANDI Yogyakarta.

Tjiptono, F. dan G. D. Ardiana. (2008). Pemasaran Strategik. Yogyakarta: ANDI Yogyakarta.

Nugroho, J S. (2003). Perilaku Konsumen: Konsep dan Implikasi untuk Strategi | dan Penelitian Bisnis Pemasaran. Jakarta: Prenada Media. 
